\title{
Heavy Metal Concentration and Mutagenic Assessment of Pond Water Samples: a Case Study from India
}

\author{
Sneh Rajput ${ }^{1}$, Tajinder Kaur ${ }^{2}$, Saroj Arora ${ }^{1}$, Rajinder Kaur ${ }^{1 *}$ \\ ${ }^{1}$ Department of Botanical and Environmental Sciences, Guru Nanak Dev University, Amritsar, Punjab, India \\ ${ }^{2}$ Department of Botany and Environmental Science, Sri Guru Granth Sahib World University, \\ Fatehgarh Sahib, Punjab, India
}

Received: 29 October 2018

Accepted: 29 January 2019

\begin{abstract}
The presence of heavy metals in an aquatic ecosystem can be directly linked to the incidences of mutagenicity in aquatic organisms. Thus, we appraised the presence of heavy metals in pond water samples and assessed their mutagenic potential. The water samples were collected for a period of two years for eight different seasons. Concentrations of heavy metals were analysed using microwave plasma atomic emission spectroscopy (MP-AES) and compared with the BIS and WHO standards for drinking water. Overall, the highest metal concentrations were detected during the winter season $(\mathrm{Cu}-564.55 \pm 9.057 \mu \mathrm{g} / \mathrm{L} ; \mathrm{Ni}-225.45 \pm 91.81 \mu \mathrm{g} / \mathrm{L} ; \mathrm{Zn}-860 \pm 48.41 \mu \mathrm{g} / \mathrm{L} ; \mathrm{Cr}-857.91 \pm 57.81 \mu \mathrm{g} / \mathrm{L})$ followed by summer (As - 18.36 $\pm 4.23 \mu \mathrm{g} / \mathrm{L} ; \mathrm{Pb}-130.93 \pm 49.73 \mu \mathrm{g} / \mathrm{L} ; \mathrm{Cd}-8.21 \pm 1.81 \mu \mathrm{g} / \mathrm{L}$ ) and monsoon season (Co $-631.96 \pm 77.09 \mu \mathrm{g} / \mathrm{L} ; \mathrm{Se}-2315.45 \pm 67.18 \mu \mathrm{g} / \mathrm{L}$ ). The lowest metal concentrations were observed during the post-monsoon season. HPI index revealed that six sampling sites out of 11 were above the critical index of 100. In mutagenicity assays we observed that samples with a higher concentration of heavy metals exhibited higher mutagenic potential. The maximum mutagenic potential was observed during the winter and summer seasons. This study can be very helpful to policy and decision makers for water resource management and conservation strategy.
\end{abstract}

Keywords: heavy metals, pond water samples, mutagenicity, Ames fluctuation assay, Vibrio harveyi bioluminescence

\section{Introduction}

The term heavy metals refer to any metallic element that possesses a specific density, mainly $>5 \mathrm{~g} / \mathrm{cm}^{3}$ [1]. Heavy metals may enter into the aquatic

*e-mail: swab2002@yahoo.com, rajinder.botenv@gndu.ac.in ecosystem by natural as well asanthropogenic activities. The widespread contamination of aquatic bodies by these metals has engrossed worldwide attention due to their persistence and bio-accumulative nature [2-3]. Heavy metal pollution can be traced back to the Roman Empire [4]. A perusal of literature reveals that heavy metal contamination has been widely reported in water samples [5], soil [6], sediments and fishes [7] and lakes [8]. Anthropogenic activities like smelting, 
mining, agricultural and industrial processes have been the source of heavy metal contamination of various environmental matrices [9]. Heavy metals are potentially mutagenic and carcinogenic in nature and are also known as oxidative stress inducers. These metals stimulate the production of reactive oxygen species, which results in DNA damage and cell death [10]. Moreover, heavy metals are bio-accumulative in nature, thus increasing the risk of several degenerative diseases like cancer [11]. A multitude of mutagenicity tests is required to study the complexity of the heavy metals in water samples. These tests should be simple, sensitive, and cost-effective [12]. In this sense, in order to evaluate the mutagenic effects of water samples, mutagenicity tests are carried out in microorganisms, including bacteria.

Ames assay using the tester strain of Salmonella typhimurium is the most commonly used method to assess the mutagenic potential of various environmental samples. Ames fluctuation assay is a modified and liquid microplate version of conventional Ames assay. Modified strains (TA98 and TA100) of Salmonella typhimurium are deficient in the production of histidine, an essential amino acid. Upon interaction with a test mutagen, a back mutation occurs which permits the bacteria to synthesise and survive in a histidine-deficient medium [13-14]. Vibrio harveyi bioluminescence assay is a rapid, sensitive and novel assay for the mutagenic assessment of marine as well as freshwater samples. It has the ability to detect the mutagenic compounds present in the sample even at a very low concentration. A dim luxE mutant strain of Vibrio harveyi (A16) is primarily used as an indicator of mutagenicity. The results evaluation is simple, as a two-fold increase in the bioluminescence by the sample as compared to the negative control is generally considered mutagenic [15]. Detailed studies have been carried out on the presence of heavy metals in rivers, lakes and wetlands, and assessing their mutagenic potential. But only a few studies have been carried on pond water. Ponds are an important part of the hydrological cycle which exhibits a self-sufficient and self-regulating ecosystem. These are exceptional freshwater resources that perform a diverse role in the biosphere, including aquifer recharge. Ponds have been identified as wetlands by Ramsar convention and literature studies [16].

Thus the present study was planned to (1) quantify heavy metals in pond water samples, (2) compare their concentrations with drinking water standards and (3) evaluate the mutagenic potential of water samples by using two bacterial assays. Ultimately, the research is important in developing water conservation and management strategies in the studied area.

\section{Materials and Methods}

The concentrations of nine metals (As, Cd, Co, $\mathrm{Cr}, \mathrm{Cu}, \mathrm{Ni}, \mathrm{Pb}, \mathrm{Se}, \mathrm{Zn}$ ) in pond water samples were studied from July 2015 to May 2017 using microwave plasma atomic emission spectroscopy (MP-AES). The mutagenicity of water samples was assessed using Ames fluctuation assay and Vibrio harveyi bioluminescence assay.

\section{Study Area}

Amritsar is one of the four districts located in the Majha region of Punjab, India. It is situated in northwestern India between $31.6340^{\circ} \mathrm{N}$ and $74.8723^{\circ} \mathrm{E}$ and is the second most-populated district of Punjab. It has an area of $2683 \mathrm{~km}^{2}$ and the region is characterized by semi-arid conditions. Mainly four seasons can be experienced in this region: monsoon (July-September);

Table 1. Sampling sites along with their coordinates.

\begin{tabular}{|c|c|c|c|c|}
\hline \multirow{2}{*}{ S. No. } & \multirow{2}{*}{ Name } & \multirow{2}{*}{ Code } & \multicolumn{2}{|c|}{ Coordinates } \\
\hline & & & Latitude & Longitude \\
\hline I & BaserkeGallan & BG & $31^{\circ} 61^{\prime} 77^{\prime \prime} \mathrm{N}$ & $74^{\circ} 71^{\prime} 90^{\prime \prime} \mathrm{E}$ \\
\hline II & Ajnala & AJ & $31^{\circ} 84^{\prime} 00^{\prime \prime} \mathrm{N}$ & $74^{\circ} 76^{\prime} 00^{\prime \prime} \mathrm{E}$ \\
\hline III & Raja Sansi & $\mathrm{RS}$ & $31^{\circ} 72^{\prime} 45^{\prime \prime} \mathrm{N}$ & $74^{\circ} 78^{\prime} 60^{\prime \prime} \mathrm{E}$ \\
\hline IV & Manawala & MW & $31^{\circ} 74^{\prime} 06^{\prime \prime} \mathrm{N}$ & $74^{\circ} 68^{\prime} 83^{\prime \prime} \mathrm{E}$ \\
\hline $\mathrm{V}$ & Majitha & MJ & $31^{\circ} 76^{\prime} 00^{\prime \prime} \mathrm{N}$ & $74^{\circ} 95^{\prime} 00^{\prime \prime} \mathrm{E}$ \\
\hline VI & Lopoke & LO & $31^{\circ} 71^{\prime} 70^{\prime \prime} \mathrm{N}$ & $74^{\circ} 63^{\prime} 27^{\prime \prime} \mathrm{E}$ \\
\hline VII & Attari & AT & $31^{\circ} 69^{\prime} 31^{\prime \prime} \mathrm{N}$ & $74^{\circ} 65^{\prime} 79^{\prime \prime} \mathrm{E}$ \\
\hline VIII & Jandiala & JA & $31^{\circ} 58^{\prime} 93^{\prime \prime} \mathrm{N}$ & $75^{\circ} 05^{\prime} 68^{\prime \prime} \mathrm{E}$ \\
\hline IX & Sathiala & SA & $31^{\circ} 55^{\prime} 50^{\prime \prime} \mathrm{N}$ & $75^{\circ} 26^{\prime} 55^{\prime \prime} \mathrm{E}$ \\
\hline$X$ & Mehta & ME & $31^{\circ} 63^{\prime} 39^{\prime \prime} \mathrm{N}$ & $74^{\circ} 87^{\prime} 22^{\prime \prime} \mathrm{E}$ \\
\hline XI & Kathunangal & $\mathrm{KN}$ & $31^{\circ} 73^{\prime} 24^{\prime \prime} \mathrm{N}$ & $75^{\circ} 02^{\prime} 31^{\prime \prime} \mathrm{E}$ \\
\hline
\end{tabular}


post-monsoon (September-November); winter (December-March) and summer (April-June). There is great variation in the weather of Amritsar during different seasons. It becomes extremely hot during summers and extremely cold in winters. Maximum temperature may reach $48^{\circ} \mathrm{C}$ during summers, whereas in winters it may go down to $4^{\circ} \mathrm{C}$. Consecutive western disturbances bring widespread rainfall during the monsoon season. For the present study four different seasons viz. monsoon (M), post-monsoon (PM), winter (W) and summer (S) were selected. Eleven different ponds located in Amritsar were selected for sampling. The sampling sites along with their coordinates are given in Table 1.

\section{Sample Collection}

The map of Amritsar District was prepared and gridding was done for the systematic collection of water samples (Fig. 1). The sampling points were fixed in terms of latitude/longitude by using a global positioning system (GPS). The sampling points were given code names and the samples were collected manually from 11 different ponds located in villages of Amritsar district of Punjab (India). Sampling was carried out in the months of July 2015 (monsoon season), October 2015 (post-monsoon season), January 2016 (winter season), May 2016 (summer season), July 2016 (monsoon season), October 2016 (post-monsoon season), January 2017 (winter season), and May 2017 (summer season). For heavy metal analysis water samples were collected in acid-washed bottles $20 \mathrm{~cm}$ below the surface of the water and digested as prescribed in the standard methods for water and wastewater analysis [17]. For biological studies, the samples were stored at $4^{\circ} \mathrm{C}$ and prior to analysis they were filter sterilized using $0.2 \mu \mathrm{m}$ membrane disc filters.
Microwave Plasma Atomic Emission Spectroscopy
(MP-AES) Operating Parameters

All the experiments were performed using an Agilent 4200 MP-AES fitted with OneNeb nebulizer, double pass glass cyclonic spray chamber and easy fit torch. Nitrogen gas was supplied using a nitrogen generator. Before every sample reading, 15 seconds uptake time and 10 seconds stabilization time was set, whereas for emission measurement of each sample, 10 seconds read time with three replicate was applied. Torch alignment and wavelength calibration were carried out using a single wavelength calibration solution. Certified reference material recoveries (CRM recoveries) are given in Table 2.

\section{Heavy Metal Pollution Index}

Heavy metal pollution index is an important technique for assessing the quality of water based on the metal pollution. It was developed by Mohan and co-workers (1996) [18]. The HPI is calculated with the following equation:

$$
\mathrm{HPI}=\mathrm{HPI}=\sum_{i=1}^{n} \mathrm{WiQi} / \sum_{i=1}^{n} \mathrm{Wi}
$$

...where Wi is the unit weightage of $i^{\text {th }}$ parameters, Qi is the sub-index of the $i^{\text {th }}$ parameter, and $n$ is the number of parameters considered.

Sub-index of the parameter (Qi) can be calculated using the formula:

$$
\mathrm{Qi}=\sum_{i=1}^{n} M i-I i / S i-I i * 100
$$

...where $\mathrm{Mi}$ is the monitored value of toxic metal after analysis; Ii is the ideal value of the $i^{\text {th }}$ parameter

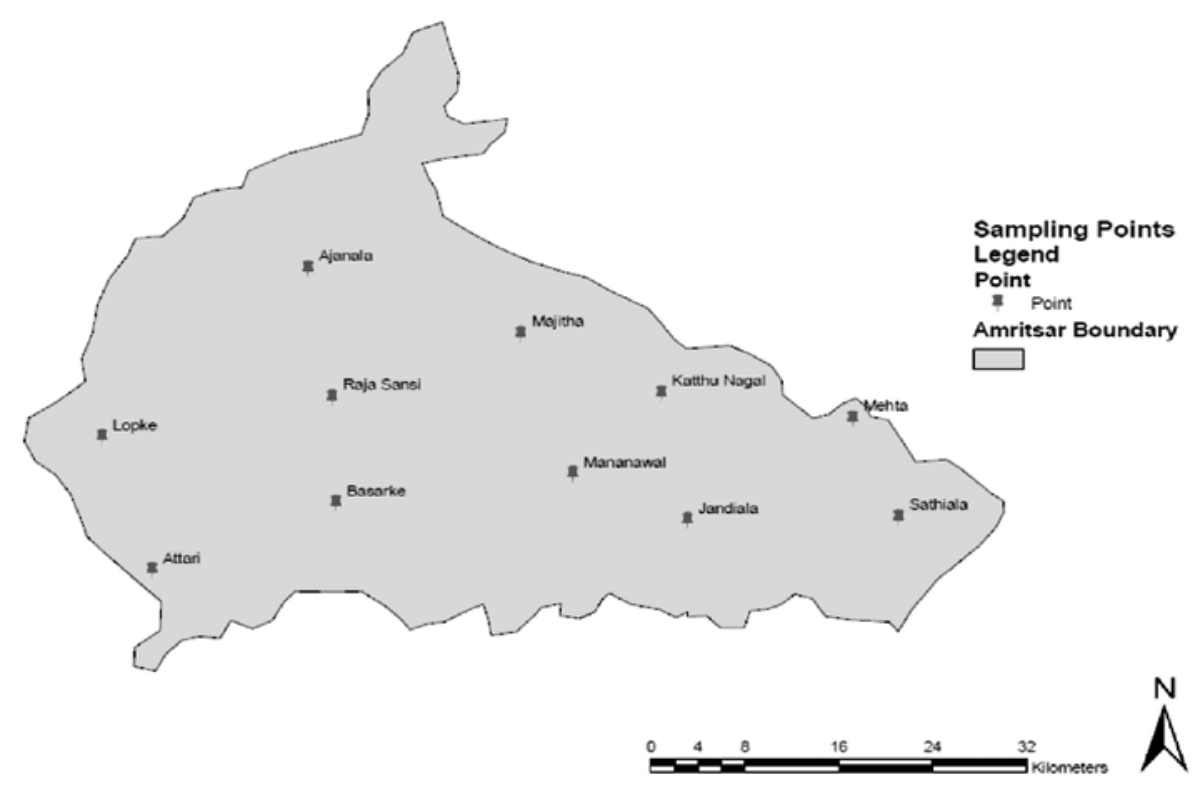

Fig. 1. Map of the study area. 
Table 2. CRM recoveries of metals.

\begin{tabular}{|c|c|c|c|}
\hline Element & $\begin{array}{c}\text { Certified Reference } \\
\text { Material value (CRM) }\end{array}$ & $\begin{array}{c}\text { Observed } \\
\text { value }\end{array}$ & $\begin{array}{c}\text { Percentage } \\
\text { recovery }\end{array}$ \\
\hline $\mathrm{As}$ & $5 \mathrm{ppm}$ & 5.00 & $100 \%$ \\
\hline $\mathrm{Cd}$ & $5 \mathrm{ppm}$ & 4.90 & $98 \%$ \\
\hline $\mathrm{Co}$ & $5 \mathrm{ppm}$ & 5.00 & $100 \%$ \\
\hline $\mathrm{Cr}$ & $5 \mathrm{ppm}$ & 4.95 & $99 \%$ \\
\hline $\mathrm{Cu}$ & $5 \mathrm{ppm}$ & 4.92 & $98.4 \%$ \\
\hline $\mathrm{Ni}$ & $5 \mathrm{ppm}$ & 4.94 & $98.8 \%$ \\
\hline $\mathrm{Pb}$ & $5 \mathrm{ppm}$ & 4.94 & $98.8 \%$ \\
\hline $\mathrm{Se}$ & $5 \mathrm{ppm}$ & 4.93 & $98.6 \%$ \\
\hline $\mathrm{Zn}$ & $5 \mathrm{ppm}$ & 4.95 & $99 \%$ \\
\hline
\end{tabular}

(specified by the Bureau of Indian Standards, 2012); and $\mathrm{Si}$ is the standard value of the $\mathrm{i}^{\text {th }}$ parameter in ppm [19]. After analysis, the concentration of each pollutant was converted into HPI. Higher HPI value indicates higher damage. Generally, 100 is considered the critical value for metal pollution index.

\section{Mutagenicity Test}

The mutagenic potential of water samples was assessed by using the Ames fluctuation assay and Vibrio harveyi bioluminescence assay. Ames fluctuation assay was performed with and without metabolic activation as described by Hubbard and co-workers with slight modifications [20]. Two-tester strain of Salmonella typhimurium (TA98 and TA100 strains) were used. Reaction mixture was prepare by adding $2.5 \mathrm{ml}$ minimal medium [Davis-Mingiloi (DM) salts (5.5×), D-glucose (200 mg/0.5 mL), D-biotin (1 mg/10 mL), L-histidine $(10 \mathrm{mg} / 10 \mathrm{~mL})$, and bromocresol purple $(1 \mathrm{mg} / 0.5 \mathrm{~mL})]$, $17.5 \mathrm{ml}$ of sterile distilled water, $20 \mu \mathrm{l}$ bacterial culture grown overnight in Luria broth and $200 \mu \mathrm{L}$ of sample. For metabolic activation, $2 \mathrm{ml}$ of $\mathrm{S} 9 \mathrm{mix}$ was added instead of $2 \mathrm{ml}$ of sterile ultrapure water. $200 \mu \mathrm{L}$ of the mixture was dispensed into 96 -well microtitre plates. The plates were then covered with lids and incubated at $37^{\circ} \mathrm{C}$ for 3-5 days.

The results were expressed as mutagenicity ration (MR) calculated by using the following formula:

MR $=$ Number of positive wells in treated plates/

Number of positive wells in negative control plates

...where positive wells contain all yellow, partially yellow, or turbid wells and all purple wells were negative.

Vibrio harveyi bioluminescence assay was carried out in accordance with the protocol given by Podgórska and Wegrzyn (2006) [21]. The A16 strain of Vibrio harveyi was procured from Podgórska and Węgrzyn (University of Gdańsk, Poland). Bacterial culture was grown in a liquid BOSS nutrient medium consisting of bacto-peptone $(1 \mathrm{~g} / 100 \mathrm{~mL})$, beef extract $(0.3 \mathrm{~g} / 100 \mathrm{~mL})$, glycerol $(11 \mathrm{mM})$, and sodium chloride $(3 \mathrm{~g} / 100 \mathrm{~mL})$ at $30^{\circ} \mathrm{C}$ for 3 hours in an incubator. $200 \mu \mathrm{l}$ of water sample was added to $5 \mathrm{ml}$ of bacterial culture and incubated further for 3 hours at $30^{\circ} \mathrm{C}$. The luminescence was measured at $575 \mathrm{~nm}$ using a multi-mode microplate reader (BioTek Synergy HT). Results are expressed as relative luminescence unit (RLU) and a twofold increase in the relative luminescence unit was considered mutagenicity of the sample.

\section{Statistical Analysis}

Data of all the experiments was calculated using Microsoft Excel 2010. The results were compared with two-way ANOVA using SPSS software version 16.0.

\section{Results}

It was observed that average concentration of metals in two years followed the pattern of $\mathrm{Se}>\mathrm{Zn}>\mathrm{Co}>\mathrm{Cr}>\mathrm{Cu}>\mathrm{Ni}>\mathrm{Pb}>\mathrm{As}>\mathrm{Cd}$. Selenium concentration in the pond water sample of all the sites during different seasons varied seasonally and ranged $0.1 \mu \mathrm{g} / \mathrm{L}$ to $2830.00 \mu \mathrm{g} / \mathrm{L}$. The highest selenium concentration was detected in a water sample collected from Mehta sampling site during the winter season of the first year of sampling (January 2016). Majitha sampling site was found to be the most zinc-contaminated site followed by $\mathrm{MW}>\mathrm{LO}>\mathrm{ME}>\mathrm{AT}>\mathrm{JA}>\mathrm{BG}>$ $\mathrm{RS}>\mathrm{AJ}>\mathrm{KN}>\mathrm{SA}$. Cobalt concentration in pond water sample of all the sites during different seasons varied seasonally, which ranged $0.1 \mu \mathrm{g} / \mathrm{L}$ to $9436 \mu \mathrm{g} / \mathrm{L}$. The highest cobalt concentration was detected in the water sample of Jandiala site during the winter season of the second year of sampling (January 2017). Chromium concentration in the pond water sample collected from all the sites during different seasons ranged $0.10 \mu \mathrm{g} / \mathrm{L}$ $1160.00 \mu \mathrm{g} / \mathrm{L}$. Maximum chromium concentration was found in the water sample collected from Manawala sampling site during the post monsoon season (October 2016). The maximum copper concentration was found in the water sample collected from Attari sampling site during winter (January 2016). It was found that the Attari sampling site was the most copper-contaminated site followed by $\mathrm{MJ}>\mathrm{MW}>\mathrm{LO}>\mathrm{KN}>\mathrm{ME}>\mathrm{JA}>\mathrm{SA}>$ $\mathrm{RS}>\mathrm{BG}>\mathrm{AJ}$. Nickel concentration in the water sample ranged from $0.1 \mu \mathrm{g} / \mathrm{L}$ to $850 \mu \mathrm{g} / \mathrm{L}$. Maximum nickel concentration was found in water samples collected from Majitha sampling site during the winter season (January 2016). During the study period, it was found that maximum lead contamination was found at Sathiala sampling site during all the seasons, followed by $\mathrm{JA}>\mathrm{AT}>\mathrm{MJ}>\mathrm{ME}>\mathrm{BG}>\mathrm{LO}>\mathrm{MW}>\mathrm{AJ}>\mathrm{KN}>\mathrm{RS}$. During the study period, the highest concentration of cobalt was observed at Baserke Gallan sampling site, followed by $\mathrm{SA}>\mathrm{AJ}>\mathrm{KN}>\mathrm{ME}>\mathrm{RS}>\mathrm{JA}>\mathrm{MW}>\mathrm{LO}>\mathrm{AT}>\mathrm{MJ}$. The concentration of arsenic in the water sample collected 
during different seasons varied seasonally. The highest value of $49.00 \mu \mathrm{g} / \mathrm{L}$ was found in the water sample of Mehta sampling site collected during the monsoon season of the second year of sampling whereas arsenic was not detected in any water sample collected during the winter and summer season of the second year of sampling. The highest cadmium concentration of $20 \mu \mathrm{g} / \mathrm{L}$ was detected in a water sample collected from Baserke Gallan, Majitha and Lopoke sampling sites during the summer season and winter (May 2016 and January 2016) of the first year of sampling, whereas cadmium was not detected in any sample collected during the winter and summer seasons of the second year of sampling (January 2017 and May 2017). Majitha was detected as the most cadmium-contaminated site, followed by $\mathrm{MW}>\mathrm{SA}>\mathrm{LO}>\mathrm{RS}>\mathrm{BG}>\mathrm{JA}>\mathrm{AT}>\mathrm{AJ}>\mathrm{ME}>\mathrm{KN}$.

\section{Mutagenicity Assays}

Both TA98 and TA100 strains of Salmonella typhimurium responded when treated with water samples collected during different seasons. However, it was observed that TA100 exhibited higher mutagenic response as compared to TA98. In TA98 strain without metabolic activation, it was observed that the water sample collected from Jandiala, Majitha and Kathunangal sampling sites during the post-monsoon season showed the highest mutagenicity ratio. In TA98 with metabolic activation, a significant increase in the mutagenicity of water samples was observed. Water samples collected from Baserke Gallan, Manawala, Jandiala, Sathiala and Kathunangal showed high mutagenic potential during the winter season of the second year of sampling. Similarly, in TA100 without metabolic activation, 1to 31-fold increases in mutagenicity were observed. The water samples collected from Manawala, Majitha, Jandiala, Sathiala and Kathunangal exhibited higher mutagenic potential during the monsoon and postmonsoon seasons of the second year of sampling. In TA100 with metabolic activation, samples exhibited significant mutagenicity. The water samples collected from Lopoke, Attari, Jandiala and Kathunangal showed highest mutagenic potential during the monsoon season of the second year of sampling.

In Vibrio harveyi bioluminescence assay all the samples showed 0.03 to 2.70 folds increase in bioluminescence level as compared to the negative control. Water samples collected from Manawala and Kathunangal were found to be highly mutagenic as compared to negative control during the winter season of the second year of sampling. Water samples of Baserke Gallan and Kathunangal showed mutagenic potential during the post-monsoon season of the second year of sampling.

\section{Discussion}

Heavy metals are potentially genotoxic and carcinogenic in nature. These metals induce oxidative

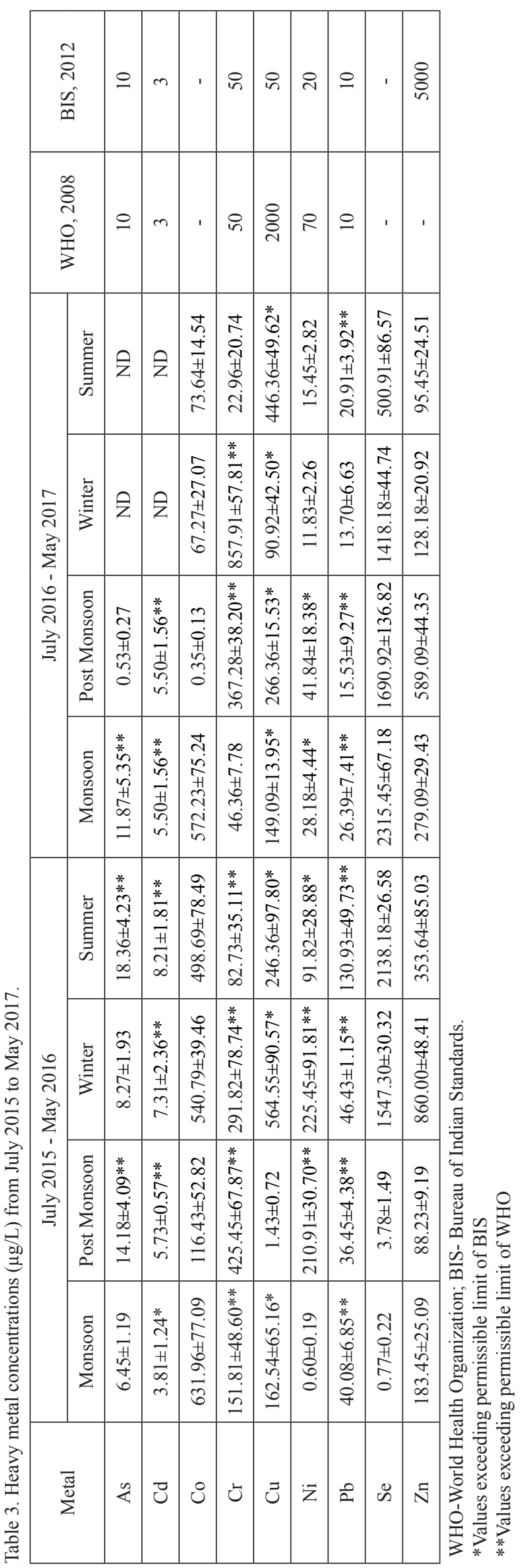


stress and the formation of reactive oxygen species leading to DNA damage. Moreover, they accumulate in nature and increase the risk of a number of degenerative diseases like cancer [22]. Higher concentrations of heavy metals in water may cause risk to all living organisms interacting with the aquatic environment [23]. Among many environmental contaminants, selenium has become a key element of concern due to its bio-accumulative nature in food webs. Selenium is a micronutrient that is required for the normal growth, development and maintenance of homeostasis [24]. However, a higher concentration of selenium causes toxic effects in the living system. Water-soluble Se enters into the food chain through uptake by fish and other aquatic biota either by gills, epidermis or gut. There is no permissible limit for selenium prescribed by national and international agencies. But several pieces of research have reported selenium toxicity in the aquatic environment [25-28]. Selenium is released from weathering of selenium-rich rocks and soil that enter into surface water through surface runoff. Precipitation is a significant governing factor of selenium distribution in water [29]. This could be the main reason for the presence of a higher concentration of selenium during the monsoon season. Moreover, anthropogenic activities like agricultural practices involving fertilizers, mining, coal combustion, insecticide production, and glass manufacture, etc. may contribute to selenium contamination in water [30]. The high content of selenium has been reported earlier in the groundwater of the Majha belt of Punjab [31]. Mining and metallurgic activities are the primary sources of $\mathrm{Zn}$ in the environment. Other sources of zinc pollution are industries, composted material, fertilizers and pesticides. The average zinc concentration in the present study was below the permissible limit set by BIS and WHO [32]. This indicates that zinc toxicity is absent in the study area. Similar results were reported by Venkatesh and co-workers in the pond water samples collected from Bhadra fish farm in Karnataka, India [33]. Kaur and Hundal also reported similar results in pond water samples of Ludhiana district, Punjab, India [34]. Cobalt is widely distributed in nature and is a part of many anthropogenic activities. It is naturally found in soil and rocks [35]. Although cobalt is a constituent of vitamin B12, extreme exposure results in various health effects, including neurological (e.g., hearing and visual impairment), haematological, respiratory and carcinogenic effects [36-37]. In the present study, cobalt was found to be the third most abundant metal in all water samples. Cobalt may enter into the environment from both natural as well as anthropogenic activities and get settled on land from windblown dust, seawater spray, volcanic eruptions, and forest fires. When rainwater washes through soil and rocks containing cobalt, it may get into surface water from runoff and leaching. Chromium is the seventh most abundant element on the earth and occurs in various oxidation states like $\mathrm{Cr}^{2+}$ to $\mathrm{Cr}^{6+}$. Chromium in its trivalent state is immobile, whereas in its hexavalent state it is highly soluble in water [38]. Anthropogenic activities like the use of fertilizers, ferro chromate refractory materials, chromium steel, metal plating, tanneries, etc., are primary sources of chromium pollution in the environment. Chromium is extremely toxic because of its oxidizing potential and permeability to biological membranes. Earlier reports have suggested that $\mathrm{Cr}^{6+}$ has caused cancer mortality in the Chinese population due to its presence in drinking water [39]. Chromium level in the present study have exceeded the permissible limit of BIS and WHO, indicating serious metal contamination in water. Copper is a widely distributed element and an important part of living organisms. Data have revealed copper concentrations exceeding the permissible limit set by BIS. The presence of $\mathrm{Cu}$ in drinking water has been associated with non-Indian childhood cirrhosis, a form of early childhood liver cirrhosis [40]. The source of copper in the water can be agricultural activities and sewage sludge [41]. Use of copper and copper alloys in water pipes and plumbing fixtures increases the risk of copper levels in the water. An increase in acidity and temperature of water increase the risk of leaching of copper in the water. Sharma and Waliahave reported the presence of $\mathrm{Cu}$ in the water samples of the Beas River (Punjab, India), and which was within the acceptable limit of BIS, 2012 [42].

Nickel is an essential metal for plants, animals and microorganisms. Toxicity symptoms occur at higher concentrations. The highest average concentration of nickel was observed during the winter of the first year of sampling. The presence of nickel in water can be attributed to municipal sewage sludge, wastewater from the sewage treatment plant and landfill site near the water resource. Brraich and Jangu (2015) have reported the presence of nickel in Harike wetland, a Ramsar site in India [43]. Lead is a bluish grey metal that occurs naturally in earth crust in trace quantities. Anthropogenic activities like mining, fuel burning and industrial operation release a higher amount of lead into the environment. The highest value of lead $(130.93 \mu \mathrm{g} / \mathrm{L})$ was recorded during the summer season, which was higher than the permissible limits of BIS and WHO. The high value of lead may be the result of the discharge of effluent, household sewage, and agricultural runoff containing phosphate fertilizer, etc., into the water body, whereas low values may be the result of the formation of complexes with organic material in soil channels. Gowd and Govil reported high concentrations of lead in surface water samples of Ranipet industrial [44]. Arsenic is a universal element that is found all over the environment [45]. It forms various toxic organic and inorganic compounds reacting with different compounds in water. Arsenic is widely distributed in soil, rocks and natural water and its compounds are used in the manufacture of insecticides, herbicides, fungicides, wood preservatives and dyestuffs. Higher values of arsenic in water can be attributed to the use of herbicides and pesticides in agricultural fields, which may enter into the water due 
Table 4. ANOVA summary table showing significant differences between sampling sites and seasons.

\begin{tabular}{|c|c|c|c|c|}
\hline Mutagenicity assay & Source of variation & Degree of freedom & F-ratio & HSD \\
\hline \multirow{4}{*}{ TA 98 without S9 mix } & Season & 7 & $520.90 *$ & \multirow{4}{*}{73.39} \\
\hline & Site & 10 & $18.68^{*}$ & \\
\hline & Season X Site & 70 & $17.58^{*}$ & \\
\hline & Residual & 176 & & \\
\hline \multirow{4}{*}{ TA 98 with S9 mix } & Season & 7 & $71.07 *$ & \multirow{4}{*}{0.62} \\
\hline & Site & 10 & $2.82 *$ & \\
\hline & Season X Site & 70 & $2.65^{*}$ & \\
\hline & Residual & 176 & & \\
\hline \multirow{4}{*}{ TA 100 without $\mathrm{S} 9$ mix } & Season & 7 & $844.55^{*}$ & \multirow{4}{*}{60.69} \\
\hline & Site & 10 & $60.55^{*}$ & \\
\hline & Season X Site & 70 & $32.61 *$ & \\
\hline & Residual & 176 & & \\
\hline \multirow{4}{*}{ TA 100 with S9 mix } & Season & 7 & $181.54^{*}$ & \multirow{4}{*}{101.68} \\
\hline & Site & 10 & $10.60 *$ & \\
\hline & Season X Site & 70 & $8.02 *$ & \\
\hline & Residual & 176 & & \\
\hline \multirow{4}{*}{$\begin{array}{l}\text { Vibrio harveyi biolumi- } \\
\text { nescence assay }\end{array}$} & Season & 7 & $16.18^{*}$ & \multirow{4}{*}{26.49} \\
\hline & Site & 10 & $1.14^{*}$ & \\
\hline & Season X Site & 70 & $0.88^{*}$ & \\
\hline & Residual & 176 & & \\
\hline
\end{tabular}

*significant at the $\mathrm{p}<0.05$ level.

to surface runoff. Arsenic forms various toxic organic and inorganic compounds reacting with different compounds in water. The presence of arsenic in drinking water results in arsenicosis, neurological effects and obstetric problems [46]. Thus, the presence of arsenic in water is of serious concern as numerous epidemiological studies have reported arsenic as a carcinogen. In the current study, arsenic was above the permissible limits of BIS and WHO. Arsenic has been reported in water, soil, sediments of Chattisgarh area of India [47]. Cadmium is a not an essential metal and exerts toxic effects on aquatic life [48-49]. It is extensively found in the earth's crust at an average concentration of $0.1 \mathrm{mg} / \mathrm{kg}$, and accumulation of cadmium in sedimentary rocks increases the cadmium concentration by up to $15 \mathrm{mg} / \mathrm{kg}$. Cadmium is used in several industrial activities like the production of alloys, pigments and batteries. Data revealed that in the present study, cadmium concentration ranged from 3.81-8.21 $\mu \mathrm{g} / \mathrm{L}$. The highest concentration of cadmium was recorded in the summer season during the first year of sampling, whereas it was absent during summer and winter season of second-year sampling. Similarly, high values of cadmium in water were recorded by Dhinamala and coworkers [50].
HPI index was used to evaluate the overall pollution of water corresponding to the presence of heavy metals in water. HPI shows the cumulative effect of each individual toxic metal on inclusive water quality. The evaluation results in the rating of toxic metals from 0 to 1 and the critical pollution index value is 100 . The rating of metals reveals the relative importance unit of individual metal quality concerns. It is inversely proportional to the recommended standard $\left(\mathrm{S}_{\mathrm{i}}\right)$ for each parameter. In the present study, maximum metal pollution was observed during the winter season, where six sampling sites out of 11 were above the critical index of 100. HPI value of RS, AJ, MW, MJ, LO, AT and SA was much higher than the critical value, which indicates high pollution load. Tiwari et al., (2015) analysed 28 surface water samples from 14 sites of the West Bokaro coalfield, India and it was found that the HPI values were lower than the critical value of 100 [51].

In the aquatic environment, trace metals are present in small quantities, but human activities, like industrial and urban sewage, agricultural and mining activities can discharge significant quantities of metals. The presence of higher quantities of metals can be linked to the formation of superoxide radical, which eventually results in the mutagenic and genotoxic 
effect. Heavy metals can exert their toxicity in a number of ways, including disrupting the nucleic acid structure, inhibiting enzymatic functioning or by displacing the essential metal from its normal binding site on a biological molecule, etc. During the current study, it was observed that the sampling sites that were contaminated with heavy metals exhibited higher mutagenic potential. The concentrations of metals like chromium, cadmium and arsenic were relatively higher in these sites. The heavy metal pollution index showed that Raja Sansi, Ajnala, Manawala, Majitha, Lopoke, Attari and Sathiala sampling sites were above the critical index value of 100 . Table 4 shows the ANOVA summary showing a significant difference between sampling sites and seasons. Sampling sites Sathiala and Lopoke were contaminated with arsenic and lead. Arsenic has been identified as a Class I human carcinogen by the International Agency of Research on Cancer. Higher concentrations of arsenic pose a threat to human health as it can undergo biotransformation from pentavalent form to trivalent form and di to mono form [52]. These arsenic forms lead to various genetic and epigenetic interruptions and affect the normal biological processes [53]. The health effects of arsenic include dysfunction of the nervous and cardiovascular systems, skin abrasions and cancer [54]. Arsenic shows its mutagenic effects by disrupting the DNA repair genes and methyltransferases, which are responsible for its biotransformation [55]. Similarly, Kumari and co-workers (2017) as reported arsenic toxicity in the aquatic environment [56]. Sampling sites Majitha and Manawala exhibited higher mutagenic potential in both bacterial assays. These sites were found to be contaminated with cadmium and chromium during the study period. Cadmium is one of the most common pollutants released from many industrial processes. It accumulates in humans and animals via exposure to cadmium-contaminated water, air and food. Exposure to cadmium is associated with dysfunction of the kidneys, liver, pancreas, testis and placenta, etc. [57]. Cadmium also alters the reduced glutathione level and induces the expression of metal lot hi one ins in the liver, ultimately leading to lipid peroxidation of cell membranes [58]. Cadmium toxicity on the glutathione level in fish is also documented [59-60].The mutagenic potential of chromium is well documented [61]. Chromium is a known mutagen that has adverse effects on animals and human beings. Chromium does not immediately pose a threat to cells due to non-permeability to cell membrane, but it has the capability to transform from one state to another. Chromium hexavalent enters into the cell through the surface transportation system and gets converted into chromium trivalent state. Trivalent chromium has the capability to induce mutagenic effects through DNA double-strand breaks, which produce chromosomal aberrations and the formation of DNA adducts, etc. [62]. The results confirmed that all water samples exhibited mutagenic potential. Certain reports are available which suggest that mutagenicity varies during different seasons. Yuan and co-workers investigated the genotoxic potential of the Yangtze and Hanshui rivers of China [63].

\section{Conclusions}

With regard to the pond ecosystem, only a few studies have focused on assessing the heavy metal contamination and mutagenicity of pond water from India. The water samples were collected for a period of two years and it was observed that average concentrations of metals followed the pattern of $\mathrm{Se}>\mathrm{Zn}>\mathrm{Co}>\mathrm{Cr}>\mathrm{Cu}>\mathrm{Ni}>\mathrm{Pb}>\mathrm{As}>\mathrm{Cd}$. Analysis revealed that the presence of high concentrations of heavy metals corresponds to the mutagenic potential of water samples. Therefore, additional research is needed to assess the mutagenic potential of water samples caused by heavy metals using a battery of bioassays. Moreover, the government should take some measures to minimize the contamination of water resources with heavy metals.

\section{Acknowledgements}

The authors are grateful to The University Grants Commission-Basic Science Research (UGC-BSR) fellowship for providing financial assistance to carry out our research work. The authors would also like to thank Satnam Singh, Department of Soil Science, Khalsa College, Amritsar for his help during the analysis. The authors also appreciate Dr Jyoti Mahajan and DrRandeep Singh, Department of Agriculture, Khalsa College, Amritsar for their timely help during the analysis.

\section{Units and Nomenclature}

As - Arsenic; $\mathrm{Cu}$ - Copper; Cr - Chromium; Ni - Nickel; Zn - Zinc; Pb - Lead; Se- Selenium; Cd Cadmium; Co - Cobalt; $\mu \mathrm{g} / \mathrm{L}$ - microgram per litre; HPI - Heavy metal pollution index; > greater than; < less than: $\mathrm{g} / \mathrm{cm}^{3}$ - gram per cubic centimetre; g- gram; DNA deoxyribonucleic acid; ${ }^{\circ} \mathrm{C}$ - degree celsius; $\mathrm{Km}^{2}$ - square kilometre; $\mu \mathrm{m}$ - micrometre; mg- milligrams; $\mu \mathrm{L}$ - micro litre; $\mathrm{mL}$ - millilitre; $\mathrm{mM}$ - millimolar; $\mathrm{nm}$ - nanometer; $\mathrm{mg} / \mathrm{kg}$ - milligram per kilogram; BIS - Bureau of Indian Standards; WHO - World Health Organization.

\section{Conflict of Interest}

The authors declare no conflict of interest.

\section{References}

1. JÄRUP L. Hazards of heavy metal contamination. Br. Med. Bull. 68 (1), 167, 2003. 
2. LIN Q., LIU E., ZHANG E., LI K., SHEN J. Spatial distribution, contamination and ecological risk assessment of heavy metals in surface sediments of Erhai Lake, a large eutrophic plateau lake in southwest China. Catena, 145, 193, 2016.

3. ZHANG Z., JUYING L., MAMAT Z., QING F.U, Y. Sources identification and pollution evaluation of heavy metals in the surface sediments of Bortala River, Northwest China. Ecotoxicol. Environ.Saf. 126, 94, 2016c.

4. NRIAGU J.O. A history of global metal pollution. Sci. 272, 223, 1996.

5. ALI M.M., ALI M.L., ISLAM M.S., Rahman M.Z. Preliminary assessment of heavy metals in water and sediment of Karnaphuli River, Bangladesh. Environ. Nanotechnol. Monit. Manage. 5, 27, 2016.

6. ALSBOU E.M.E., AL-KHASHMAN O.A. Heavy metal concentrations in roadside soil and street dust from Petra region, Jordan. Environ. Monit. Assess. 190 (1), 48, 2018.

7. FERNANDEZ-MAESTRE R., JOHNSON-RESTREPO B., OLIVERO-VERBEL J. Heavy Metals in Sediments and Fish in the Caribbean Coast of Colombia: Assessing the Environmental Risk. Int. J. Environ. Res. 1, 2018.

8. RAJESHKUMAR S., LI X. Bioaccumulation of heavy metals in fish species from the Meiliang Bay, Taihu Lake, China. Toxicol. Rep. 5, 288, 2018.

9. AUDRY S., SCHAFER J., BLANC G., JOUANNEAU J.M. Fifty-year sedimentary record of heavy metal pollution $(\mathrm{Cd}, \mathrm{Zn}, \mathrm{Cu}, \mathrm{Pb})$ in the Lot River reservoirs (France). Environ. Pollut. 132, 413, 2004.

10. LUSHCHAK V.I. Environmentally induced oxidative stress in aquatic animals. Aquat. Toxicol. 101 (1), 13, 2011.

11. BEYERSMANN D., HARTWIG A. Carcinogenic metal compounds: recent insight into molecular and cellular mechanisms. Arch. Toxicol. 82 (8), 493, 2008.

12. TABREZ S., SHAKIL S., UROOJ M., DAMANHOURI G.A., ABUZENADAH A.M., AHMAD M. Genotoxicity testing and biomarker studies on surface waters: an overview of the techniques and their efficacies. J. Environ. Sci. Health., Part C. 29 (3), 250, 2011.

13. AMES B.N. Identifying environmental chemicals causing mutations and cancer. Sci. 204 (4393), 587, 1979.

14. MORTELMANS K., ZEIGER E. The Ames Salmonella/ microsome mutagenicity assay. Mutat. Res. 455 (1), 29, 2000.

15. PODGÓRSKA B., WĘGRZYN G. A modified Vibrio harveyi mutagenicity assay based on bioluminescence induction. Lett. Appl. Microbiol. 42 (6), 578, 2006.

16. LINTON S., GOULDER R. Botanical conservation value related to origin and management of ponds. Aquat. Conserv. Mar. Freshwater Ecosyst. 10 (2), 77, 2000.

17. Standard Methods for the Examination of Water and Waste Waters $\left(22^{\text {st }}\right.$ Edn). American water works Association (AWWA), water pollution control Federation (WPCF) and American Public Health Association (APHA). Washington DC, USA, 2012.

18. MOHAN S.V., NITHILA P., REDDY S.J. Estimation of heavy metals in drinking water and development of heavy metal pollution index. J. Environ. Sci. Health A. 31 (2), 283, 1996.

19. STANDARD I. Bureau of Indian Standards drinking water specifications. BIS, 10500, 2012.

20. HUBBARD S.A., GREEN M.H.L., GATEHOUSE D., BRIDGES J.W. The fluctuation test in bacteria. Handbook of mutagenicity test procedures, 141, 1984.
21. PODGÓRSKA B., WĘGRZYN G. A modified Vibrio harveyi mutagenicity assay based on bioluminescence induction. Lett. Appl. Microbiol. 42 (6), 578, 2006.

22. BEYERSMANN D., HARTWIG A. Carcinogenic metal compounds: recent insight into molecular and cellular mechanisms. Arch. Toxicol. 82 (8), 493, 2008.

23. AKINBORO A., MOHAMED K.B., ASMAWI M.Z., SULAIMAN S.F., SOFIMAN O.A. Antioxidants in aqueous extract of Myristicafragrans (Houtt.) suppress mitosis and cyclophosphamide-induced chromosomal aberrations in Allium cepa L. cells. J. Zhejiang Univ. Sci. B. 12 (11), 915, 2011.

24. BAJAJ M., EICHE E., NEUMANN T., WINTER J., GALLERT C. Hazardous concentrations of selenium in soil and groundwater in North-West India. J. Hazard. Mater. 189 (3), 640, 2011.

25. LEMLY A. Selenium poisoning of fish by coal ash wastewater in Herrington Lake, Kentucky. Ecotoxicol Environ Saf. 150, 49, 2018.

26. LAJÇI N., SADIKU M., LAJÇI X., BARUTI B., NIKSHIQ S. Assessment of Major and Trace Elements of Fresh Water Springs in Village Pepaj, Rugova Region, Kosova. J. Int. Environ. Appl. Sci. 12 (2), 112, 2017.

27. MAL J., VENEMAN W.J., NANCHARAIAH Y.V., VAN HULLEBUSCH E.D., PEIJNENBURG W.J., VIJVER M.G., LENS P.N. A comparison of fate and toxicity of selenite, biogenically, and chemically synthesized selenium nanoparticles to zebrafish (Danio rerio) embryogenesis. Nanotoxicology, 11 (1), 87, 2017.

28. SHARMA V.K., MCDONALD T.J., SOHN M., ANQUANDAH G.A., PETTINE M., ZBORIL R. Assessment of toxicity of selenium and cadmium selenium quantum dots: A review. Chemosphere, 188, 403, 2017.

29. DHILLON K.S., DHILLON S.K. Selenium in groundwater and its contribution towards daily dietary Se intake under different hydrogeological zones of Punjab, India. J. Hydrol. 533, 615, 2016.

30. HE Y., XIANG Y., ZHOU Y., YANG Y., ZHANG J., HUANG H., SHANG C., LUO L., GAO J., TANG L. Selenium contamination, consequences and remediation techniques in water and soils: A review. Environ. Res. 164, $288,2018$.

31. VIRK H.S. Selenium Contamination of Groundwater of MajhaBelt of Punjab (India). Res. Rev. J. Toxicol. 8 (2), 1, 2018.

32. World Health Organization. Guidelines for drinking-water quality: second addendum. Vol. 1, Recommendations. World Health Organization, 2008.

33. VENKATESH N. Evaluation of heavy metals in the water of fish ponds at Bhadra Fish Farm, Karnataka. Int. J. Eng. Res. Mod. Educ. 1 (2), 47, 2016.

34. KAUR H., HUNDAL S.S. Heavy metal accumulation in some selected ponds of district Ludhiana (Punjab), India. Int. J. Chem. Studies.6(1), 1739-1743, 2018.

35. BARRIO-PARRA F., ELÍO J., DE MIGUEL E., GARCÍAGONZÁLEZ J.E., IZQUIERDO M., ÁLVAREZ R. Environmental risk assessment of cobalt and manganese from industrial sources in an estuarine system. Environ. Geochem. Health. 40 (2), 737, 2018.

36. LEYSSENS L., VINCK B., VAN DER STRAETEN C., WUYTS F., MAES L. Cobalt toxicity in humans - A review of the potential sources and systemic health effects. Toxicology, 387, 43, 2017.

37. BHUYAN M.S., BAKAR M.A. Seasonal variation of heavy metals in water and sediments in the Halda River, 
Chittagong, Bangladesh. Environ. Sci. Pollut. Res. 24 (35), 27587, 2017.

38. WOLIŃSKA A., STĘPNIEWSKA Z., WŁOSEK R. The influence of old leather tannery district on chromium contamination of soils, water and plants. Nat. Sci. 5 (02), $253,2013$.

39. ZHANG J., LI S. Cancer mortality in a Chinese population exposed to hexavalent chromium in water. JOEM. 39 (4), 315, 1997.

40. ZIETZ B.P., DIETER H.H., LAKOMEK M., SCHNEIDER H., KEßLER-GAEDTKE B., DUNKELBERG H. Epidemiological investigation on chronic copper toxicity to children exposed via the public drinking water supply. Sci. Total Environ. 302 (1-3), 127, 2003.

41. HUSSAIN J., HUSAIN I., ARIF M., GUPTA N. Studies on heavy metal contamination in Godavari river basin. Appl. Water Sci. 7 (8), 4539, 2017.

42. SHARMA S., WALIA Y.K. Water Quality Assessment of River Beas During Winter Season in Himachal Pradesh, India. Current World Environ. 11 (1), 194, 2016.

43. BRRAICH O.S., JANGU S. Evaluation of water quality pollution indices for heavy metal contamination monitoring in the water of Harike Wetland (Ramsar Site), India. IJSRP, 5 (2), 1, 2015.

44. GOWD S.S., GOVIL P.K. Distribution of heavy metals in surface water of Ranipet industrial area in Tamil Nadu, India. Environ. Monit. Assess. 136 (1-3), 197, 2008.

45. ATSDR. Toxicological profile for arsenic TP-92/09. Centre for Disease Control, Agency for Toxic Substances and Disease Registry, Atlanta, GA, 2000.

46. GARA T., FENGTING L., NHAPI I., MAKATE C., GUMINDOGA W. Health safety of drinking water supplied in Africa: a closer look using applicable water-quality standards as a measure. Expo. Health, 1, 2017.

47. PATEL K.S., SHRIVAS K., BRANDT R., JAKUBOWSKI N., CORNS W., HOFFMANN P. Arsenic contamination in water, soil, sediment and rice of central India. Environ. Geochem. Health. 27 (2), 131, 2005.

48. EDOKPAYI J.N., ODIYO J.O., POPOOLA O.E., MSAGATI T.A. Assessment of Trace metals contamination of surface water and sediment: A case study of Mvudi River, South Africa. Sustainability, 8 (2), 135, 2016.

49. EL-ALFY M.A.H., EL-AZIM H.A., EL-AMIER Y.A. Assessment of heavy metal contamination in surface water of Burullus Lagoon, Egypt. J. Agric. Sci. 1, 233, 2017.

50. DHINAMALA K., PUSHPALATHA M., SAMUEL T., RAVEEN R. Seasonal variation in the distribution of heavy metals in surface waters from Pulicat lake, Tamil Nadu, India. Int. J. Fish. Aquat. 3 (2), 260, 2015.

51. TIWARI A.K., DE MAIO M., SINGH P.K., MAHATO M.K. Evaluation of surface water quality by using GIS and a heavy metal pollution index (HPI) model in a coal mining area, India. Bull. Environ. Contam. Toxicol. 95 (3), 304, 2015.
52. MINATEL B.C., SAGE A.P., ANDERSON C., HUBAUX R., MARSHALL E.A., LAM W.L., MARTINEZ V.D. Environmental arsenic exposure: From genetic susceptibility to pathogenesis. Environ. Int. 112, 183, 2018.

53. SAGE A.P., MINATEL B.C., NG K.W., STEWART G.L., DUMMER T.J., LAM W.L., MARTINEZ V.D. Oncogenomic disruptions in arsenic-induced carcinogenesis. Oncotarget, 8 (15), 25736, 2017.

54. BELLAMRI N., MORZADEC C., FARDEL O., VERNHET L. Arsenic and the immune system. Curr Opin Toxicol. 2018.

55. PAUL D., KAZY S.K., GUPTA A.K., PAL T., SAR P. Diversity, metabolic properties and arsenic mobilization potential of indigenous bacteria in arsenic contaminated groundwater of West Bengal, India. PloSone, 10 (3), e0118735, 2015

56. KUMARI B., KUMAR V., SINHA A.K., AHSAN J., GHOSH A.K., WANG H., DEBOECK G. Toxicology of arsenic in fish and aquatic systems. Environ. Chem. Lett. 15 (1), 43, 2017.

57. MARETTOVÁ E., MARETTA M., LEGÁTH J. Toxic effects of cadmium on testis of birds and mammals: a review. Anim. Reprod. Sci. 155, 1, 2015.

58. SEVCIKOVA M., MODRA H., SLANINOVA A., SVOBODOVA Z. Metals as a cause of oxidative stress in fish: a review. Vet Med. 56 (11), 537, 2011.

59. CAO L., HUANG W., LIU J., YIN X., DOU S. Accumulation and oxidative stress biomarkers in Japanese flounder larvae and juveniles under chronic cadmium exposure. Comp. Biochem. Physiol. C: Toxicol. Pharmacol. 151 (3), 386, 2010

60. JIA X., ZHANG H., LIU X. Low levels of cadmium exposure induce DNA damage and oxidative stress in the liver of Oujiangcolored common carp Cyprinuscarpio var. color. Fish Physiol Biochem. 37 (1), 97, 2011.

61. DO NASCIMENTO MONTEIRO J.A., DA CUNHA L.A., DA COSTA M.H.P., DOS REIS H.S., DA SILVA AGUIAR A.C., DE OLIVEIRA-BAHIA V.R.L., BURBANO R.M.R., DA ROCHA C.A.M. Mutagenic and histopathological effects of hexavalent chromium in tadpoles of Lithobatescatesbeianus (Shaw, 1802) (Anura, Ranidae). Ecotoxicol Environ Saf. 163, 400, 2018.

62. MATSUMOTO S.T., MANTOVANI M.S., MALAGUTTII M.I.A., DIAS A.L., FONSECA I.C., MARIN-MORALES M.A. Genotoxicity and mutagenicity of water contaminated with tannery effluents, as evaluated by the micronucleus test and comet assay using the fish Oreochromisniloticus and chromosome aberrations in onion root-tips. Genet. Mol. Biol. 29 (1), 148, 2006

63. YUAN J., WU X.J., LU W.Q., CHENG X.L., CHEN D., LI X.Y., LIU A.L., WU J. J., XIE H., STAHL T., MERSCHSUNDERMANN V. Chlorinated river and lake water extract caused oxidative damage, DNA migration and cytotoxicity in human cells. Int. J. Hyg. Environ. Health. 208 (6), 481, 2005. 